\title{
Pengetahuan Keamanan Pangan Mahasiswa Mengenai Lima Kunci Keamanan Pangan Keluarga
}

\author{
Food Safety Knowledge of College Students \\ About Five Keys of Food Safety for Family
}

\author{
Marcellinus Elwan Tenggana ${ }^{1)}$, Winiati P. Rahayu ${ }^{1,2)^{*}}$, dan Ratna Wulandari ${ }^{3)}$ \\ ${ }^{1)}$ Departemen Ilmu dan Teknologi Pangan, Fakultas Teknologi Pertanian, Institut Pertanian Bogor, Bogor \\ ${ }^{2)}$ South East Asian Food and Agricultural Science and Technology, Institut Pertanian Bogor, Bogor \\ ${ }^{3)}$ Direktorat PMPU-Badan Pengawas Obat dan Makanan, Republik Indonesia, Jakarta
}

\begin{abstract}
Development of the Five Keys for Family Food Safety module for food safety cadres needs to be done to facilitate cadres in understanding the material provided. This study aims to analyze the food safety knowledge of college students and evaluate the Five Keys for Family Food Safety teaching materials developed by the Badan POM. The respondents of the survey were college student of IPB University. The results of the evaluation of food safety knowledge of college students after being educated using the Five Keys for Family Food Safety module showed an increasing in the value of knowledge by $16 \%$. The initial value of college student knowledge was 71 and increased became $87 \%$. Non-parametric test results indicate that there were significant differences between the two values with the Sig. 2 tailed at 0.000. The evaluation results of the Five Keys for Family Food Safety module show very good criteria with an average value of $81 \%$. The values for display, material content and benefit were 81, 82, and 78\%. This indicate that Five Keys for Family Food Safety module is ready to be used as teaching material for food safety.
\end{abstract}

Keywords: college students, food safety, knowledge, teaching materials

\begin{abstract}
Abstrak. Pengembangan modul Lima Kunci Keamanan Pangan Keluarga bagi kader keamanan pangan perlu dilakukan agar mempermudah kader dalam memahami materi yang diberikan. Penelitian ini bertujuan menganalisis pengetahuan keamanan pangan mahasiswa dan mengevaluasi bahan ajar Lima Kunci Keamanan Pangan Keluarga yang dikembangkan oleh Badan POM. Responden dari survei yang dilakukan adalah 100 mahasiswa IPB University. Pengetahuan keamanan pangan mahasiswa setelah diedukasi menggunakan modul Lima Kunci Keamanan Pangan Keluarga meningkat sebesar 16\%, dengan nilai sebelum diedukasi adalah 71 dan setelah diedukasi menjadi 87\%. Hasil pengujian non parametrik menunjukkan adanya perbedaan yang signifikan antara hasil pre dan post-test dengan nilai Sig. 2 tailed sebesar 0.000. Hasil evaluasi bahan ajar Lima Kunci Keamanan Pangan Keluarga menunjukkan kriteria yang sangat baik dengan rata-rata nilai sebesar $81 \%$. Masing-masing nilai untuk tampilan, isi materi dan manfaat sebesar 81, 82, dan 78\%. Modul Lima Kunci Keamanan Pangan Keluarga telah siap digunakan sebagai bahan materi penyuluhan keamanan pangan.
\end{abstract}

Kata Kunci: bahan ajar, keamanan pangan, mahasiswa, pengetahuan

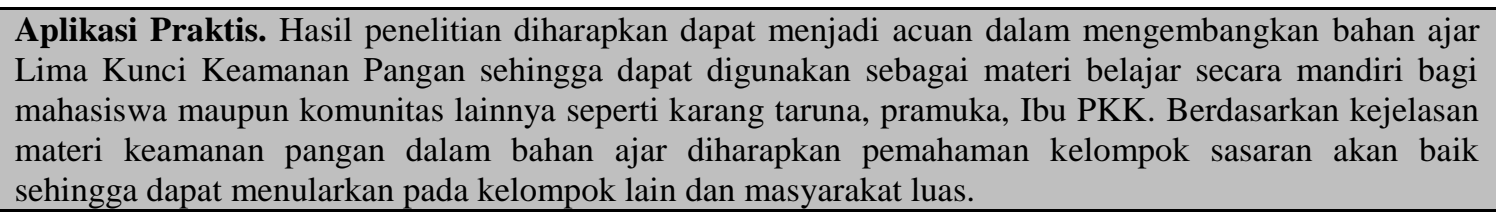

\section{PENDAHULUAN}

Keamanan pangan merupakan hal yang harus diperhatikan agar produk pangan aman dikonsumsi; bebas dari bahan yang menyebabkan sakit berupa cemaran mikroba, bahan kimia beracun, maupun benda asing. Menurut UU No. 18 tahun 2012 tentang pangan, keamanan pangan merupakan suatu kondisi dan upaya yang perlu dilakukan untuk mencegah pangan dari

Korespondensi: wini_a@hotmail.com kemungkinan cemaran biologis, kimia, dan fisik yang dapat merugikan, mengganggu, serta membahayakan kesehatan manusia dan tidak bertentangan dengan agama, keyakinan, dan budaya masyarakat sehingga aman untuk dikonsumsi. Kejadian luar biasa (KLB) keracunan pangan yang terjadi di suatu negara menunjukkan tingkat keamanan pangan negara tersebut. Menurut Permenkes nomor 2 tahun 2013 tentang kejadian luar biasa (KLB) keracunan pangan, KLB keracunan pangan merupakan peristiwa ketika terdapat dua atau lebih orang yang menderita sakit dengan gejala 
yang sama atau hampir sama setelah mengonsumsi pangan, dan berdasarkan analisis epidemiologi, pangan yang dikonsumsi tersebut sebagai penyebab keracunan. Berdasarkan laporan tahunan Badan Pengawas Obat dan Makanan Republik Indonesia (BPOM RI) dari tahun 2015 hingga 2018 dilihat dari jenis pangan penyebab KLB keracunan pangan, pangan hasil olahan rumah tangga memiliki persentase terbesar dibandingkan dengan pangan jajanan, pangan jasa boga, dan pangan olahan. Secara berturut-turut dari 2015 hingga 2018 persentase KLB keracunan pangan akibat masakan rumah tangga sebesar, 40.98, 49.15, 37.74, dan $42.86 \%$ (BPOM 2015; 2016; 2017; 2018). Data tersebut menunjukkan risiko terjadinya KLB keracunan pangan yang tinggi pada pangan hasil olahan rumah tangga. Oleh karena itu, perlu adanya edukasi keamanan pangan kepada masyarakat mengenai keamanan pangan keluarga.

Maka dari itu, BPOM khususnya Direktorat Pemberdayaan Masyarakat dan Pelaku Usaha (PMPU) melaksanakan suatu program yang disebut dengan Bimbingan Teknis Kader Keamanan Pangan Nasional. Program tersebut melibatkan organisasi masyarakat dan pramuka melalui penyelenggaraan bimbingan teknis. Adanya Kader Keamanan Pangan Nasional diharapkan dapat memberdayakan dan meningkatkan partisipasi individu masyarakat untuk mengadopsi praktik keamanan pangan yang baik dan dapat berperan aktif sebagai perantara atau penghubung antara BPOM dan unit pelaksana teknisnya dengan komunitas masyarakat terkait isu/masalah keamanan pangan. Selain melalui organisasi masyarakat, karang taruna, dan pramuka, mahasiswa sebagai agen perubahan juga dapat diberdayakan dalam menyampaikan keamanan pangan kepada masyarakat. Hal tersebut dikarenakan pada Tri Dharma Perguruan Tinggi, salah satu tugas mahasiswa yakni mengabdi kepada masyarakat. Langkah yang dapat dilakukan untuk meningkatkan pengetahuan keamanan mahasiswa salah satunya dengan memberikan materi edukasi Lima Kunci Keamanan Pangan Keluarga. Penelitian yang dilakukan bertujuan untuk mengetahui daya terima pengetahuan bagi mahasiswa setelah diedukasi dengan Lima Kunci Keamanan Pangan Keluarga, serta mengevaluasi materi edukasi Lima Kunci Keamanan Pangan Keluarga yang disajikan secara daring sebagai bahan ajar baik dari tampilan maupun isi materinya.

\section{BAHAN DAN METODE}

\section{Bahan}

Penelitian ini menggunakan bahan ajar Lima Kunci Keamanan Pangan Keluarga yang dibuat dan dalam tahap pengembangan oleh Badan POM yang dimulai pada tahun 2020. Selain itu penelitian ini juga menggunakan kuesioner pre dan post test pengetahuan keamanan pangan, serta kuesioner evaluasi bahan ajar.

\section{Penentuan sampel responden (Sugiyono 2008)}

Penentuan responden yang dilakukan pada observasi ini menggunakan teknik non-probability sampling design dengan metode purposive sampling. Nonprobability random sampling adalah suatu metode sampling yang setiap elemen populasinya tidak mempunyai kemungkinan yang sama untuk dijadikan sampel. Metode purposive samping adalah suatu teknik dalam mengambil sampel dengan menentukan kriteria-kriteria tertentu atau seleksi khusus. Penggunaan metode nonprobability sampling dengan purposive sampling diharapkan memberikan hasil pengujian yang lebih spesifik karena menyasar kriteria atau target tertentu. Penelitian ini mengambil responden mahasiswa IPB University yang telah memenuhi kriteria inklusi dan eksklusi. Kriteria inklusi dalam penelitian ini adalah mahasiswa S-1 angkatan 2017 (angkatan 54), aktif dalam kegiatan perkuliahan, hendak melaksanakan kegiatan kuliah kerja nyata $(\mathrm{KKN})$, bukan mahasiswa Departemen Ilmu Gizi atau Ilmu dan Teknologi Pangan, bersedia menjadi responden. Kriteria eksklusi yang ditetapkan dalam penelitian ini antara lain, mahasiswa D3, S2, S3, sedang cuti/tidak aktif dalam kegiatan perkuliahan, tidak mengikuti kegiatan $\mathrm{KKN}$, merupakan mahasiswa Departemen Ilmu Gizi atau Ilmu dan Teknologi Pangan. Populasi mahasiswa S1 angkatan 2017 (angkatan 54) berdasarkan data yang diperoleh dari IPB University (2019), sebanyak 4.008 orang. Jumlah tersebut kemudian dikurangi dengan jumlah mahasiswa dari Departemen Ilmu dan Tekonologi Pangan dan Ilmu Gizi sehingga diperoleh sebanyak 3.814 orang. Jumlah sampel kemudian dihitung dengan menggunakan rumus Slovin sebagai berikut:

$$
\mathrm{n}=\frac{\mathrm{N}}{1+\mathrm{Ne}^{2}}
$$

dimana, $\mathrm{n}=$ sampel penelitian (mahasiswa yang menjadi responden); $\mathrm{N}=$ populasi mahasiswa $\mathrm{S} 1$ angkatan 2017 (angkatan 54); e = toleransi eror sebesar $10 \%$.

Toleransi eror sebesar $10 \%$ digunakan untuk meminimalisir jumlah sampel yang digunakan, namun tetap memberikaan tingkat kesalahan yang kecil. Berdasarkan perhitungan menggunakan rumus Slovin dengan toleransi eror sebesar $10 \%$ diperoleh jumlah responden sebesar 97 orang dan dibulatkan menjadi 100 orang.

\section{Penyusunan kuesioner pre \& post-test dan materi edukasi (Adillah 2019, Budiaji 2013)}

Jenis pertanyaan pada kuesioner pre \& post-test yang digunakan adalah kuesioner tertutup, yaitu pertanyaan yang tidak memungkinkan responden untuk memberikan jawaban bebas, hanya memilih jawaban yang sudah disediakan. Penggunaan kuesioner tertutup bertujuan untuk meminimalkan variasi jawaban yang diberikan oleh responden. Kuesioner terdiri dari 30 pertanyaan tertutup dan dibagi menjadi dua blok yaitu blok karakteristik responden dan pertanyaan tentang 
keamanan pangan. Blok karakteristik responden merupakan pertanyaan mengenai data umum responden seperti nama, usia, pendidikan, dan pekerjaan. Blok pertanyaan keamanan pangan merupakan pertanyaan terkait pengetahuan mengenai keamanan pangan yang mengacu pada materi Lima Kunci Keamanan Pangan Keluarga BPOM yang dibuat pada tahun 2020. Kuesioner yang sudah disusun kemudian diuji validitas dan reliabilitasnya untuk menentukan kelayakan kuesioner pada pengujian selanjutnya.

Kuesioner evaluasi materi edukasi Lima kunci keamanan pangan keluarga yang digunakan menggunakan pertanyaan tertutup dan terbuka. Kuesioner tertutup memiliki jenis pertanyaan yang membatasi responden dalam memberikan jawaban dengan cara menyediakan beberapa pilihan jawaban untuk dipilih oleh responden, serta berguna untuk meminimalisir variasi. Kuesioner terbuka yang digunakan berfungsi untuk memberikan kebebasan responden untuk berpendapat atau memberikan masukan terhadap materi edukasi yang diujikan. Pertanyaan tertutup akan diukur dengan menggunakan skala likert. Penggunaan skala likert meliputi empat titik respon yaitu, sangat setuju, setuju, tidak setuju, dan sangat tidak setuju. Jawaban netral tidak disertakan untuk mengurangi bias pada jawaban responden.

\section{Uji validitas dan reliabilitas kuesioner (Ananda 2016)}

Validitas diartikan sebagai keabsahan alat ukur, artinya alat ukur dapat digunakan dalam pengukuran dengan baik. Oleh karena itu, validitas adalah ukuran yang menunjukkan tingkat kesesuaian alat ukut (Triana dan Widyarto 2013). Uji validitas dilakukan dengan memilih total responden sebanyak 30 orang yang tidak termasuk dalam kriteria uji. Pemilihan responden uji coba sebanyak 30 orang mengacu kepada Umar (2008), yang menyatakan bahwa jumlah minimal responden sebesar 30 orang, dengan jumlah tersebut distribusi nilai (skor) akan lebih mendekati kurva normal dengan tingkat kepercayaan 95\%. Hasil uji validitas diolah menggunakan perangkat lunak SPSS 25.0 for windows. Nilai signifikansi dari masing-masing pertanyaan dibandingkan dengan nilai total pertanyaan, jika nilainya $<\alpha$ menandakan bahwa pertanyaan tersebut sudah valid. Jika ada pertanyaan yang tidak valid setelah pengujian, maka dapat diputuskan untuk membuang atau memperbaiki pertanyaan tersebut. Uji reliabilitas digunakan untuk menguji tingkat kekonsistenan kuesioner ketika digunakan berulang kali. Oleh karena itu, reliabilitas merupakan suatu indikator dalam menunjukkan tingkat kepercayaan suatu alat ukur (Widi 2011). Uji reliabilitas dilakukan dengan menggunakan korelasi alpha cronbach's pada perangkat lunak SPSS Statistic 25.0 for windows. Uji reliabilitas menunjukkan hasil yang reliabel apabila dalam pengujiannya memiliki nilai alpha cronbach's lebih besar atau sama dengan 0.70 (Hadisa et al. 2017).

\section{Pelaksanaan evaluasi pengetahuan dan materi edukasi (Adillah 2019)}

Pengisian kuesioner dilakukan sebelum (pre) dan sesudah (post) diadakannya program intervensi (edukasi). Tujuannya untuk mengetahui skor pengetahuan responden sebelum diberikan edukasi dan setelah diberikan edukasi. Output yang diharapkan adalah meningkatnya nilai pengetahuan keamanan pangan responden. Mekanisme evaluasi pengetahuan keamanan pangan terdiri dari empat tahapan. Tahap pertama evaluasi meliputi pre-test pengetahuan keamnan pangan responden, pemberian materi edukasi Lima Kunci Keamanan Pangan Keluarga dilakukan secara daring dalam bentuk file $P D F$ yang link-nya sudah disertakan dalam kuesioner dan dapat diakses secara mandiri, setelah responden membaca materi secara mandiri kemudian ada diskusi serta penjelasan terkait materi yang diberikan secara daring, setelah penjelasan kemudian dilakukan post-test untuk mengukur peningkatan pengetahuan keamanan pangan responden setelah diedukasi menggunakan materi Lima Kunci Keamanan Pangan Keluarga. Setelah evaluasi pengetahuan pangan selesai, kemudian responden diminta untuk menjawab pertanyaan terkait evaluasi materi edukasi. Tahapan beserta waktu pelaksanaannya dapat dilihat pada (Tabel 1).

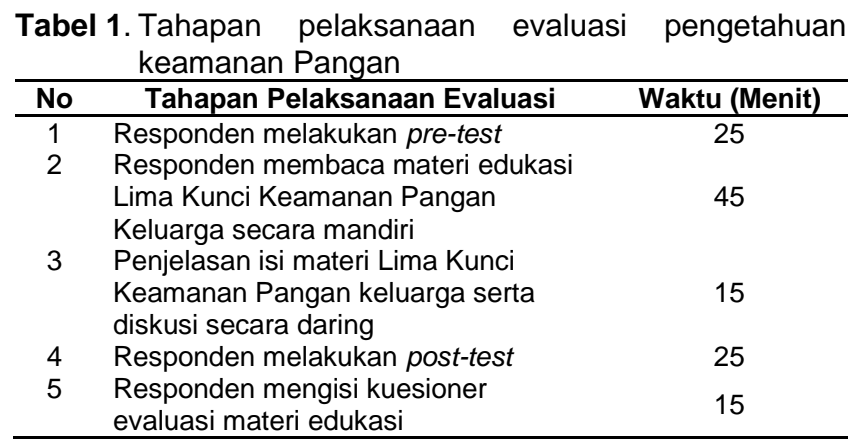

\section{Analisis hasil evaluasi pengetahuan dan materi edukasi}

Nilai hasil pengujian pre-test dan post-test mahasiswa yang diperoleh kemudian diolah melalui tahapan editing, coding, dan processing. Perhitungan skor pengetahuan setiap nomor dihitung menggunakan rumus berikut ini.

\section{Skor Pengetahuan $=\frac{\text { jumlah responden benar }}{\text { total jumlah responden }} \times 100 \%$}

Pengkategorian pengetahuan merujuk kepada Nursalam (2008) yang dibagi menjadi tiga kategori sebagai berikut, 76-100\% menunjukkan tingkat pengetahuan yang baik; $56-75 \%$ menunjukkan tingkat pengetahuan yang cukup baik; $<56 \%$ menunjukkan tingkat pengetahuan yang kurang baik. Setelah processing dilakukan analisis statistik menggunakan program SPSS 25.0.

Uji normalitas data pada hasil pre dan post-test digunakan untuk menentukan normalitas data. Uji beda pada hasil pengujian pre dan post-test untuk melihat 
pengaruh edukasi terhadap nilai pengetahuan dengan menggunakan uji paired sample t-test apabila data berdistribusi normal dan menggunakan uji Wilcoxon apabila data tidak berdistribusi normal. Selain itu, uji beda juga dilakukan untuk mengetahui pengaruh jenis kelamin dan Fakultas asal mahasiswa terhadap peningkatan nilai pengetahuan. Uji yang digunakan untuk pengaruh jenis kelamin dengan menggunakan uji independent t-test apabila data pengujian berdistribusi dengan normal dan menggunakan uji Mann-Whitney apabila data tidak berdistribusi dengan normal. Uji yang digunakan untuk pengaruh Fakultas dengan menggunakan uji one way anova apabila data berdistribusi normal dan uji Kruskal-Wallis apabila data berdistribusi tidak normal.

Analisis evaluasi materi edukasi Lima Kunci Keamanan Pangan Keluarga dilakukan dengan menghitung masing-masing sub-indikator penilaian dengan menggunakan rumus yang tertera sebagai berikut ini.

$$
\text { Skor Penilaian }=\frac{\text { jumlah skor yang diperoleh }}{\text { total skor maksimum }} \times 100 \%
$$

Persentase nilai yang diperoleh dari pengujian kemudian diukur menggunakan interpretasi skor untuk skala likert (Febrianti et al. 2017), yaitu sebagai berikut $0-25 \%$ berarti sangat tidak baik; $26-50 \%$ berarti tidak baik; $51-75 \%$ berarti baik; 76-100\% berarti sangat baik. Bahan ajar yang diteliti dinilai layak untuk digunakan jika setelah data kuesioner diolah memberikan nilai antara 51 sampai $100 \%$, atau masuk ke dalam kategori penilaian baik dan sangat baik.

\section{HASIL DAN PEMBAHASAN}

\section{Validitas dan reliabilitas kuesioner keamanan pangan}

Pengujian validitas menunjukkan 30 pertanyaan dalam kuesioner keamanan pangan sudah valid dengan nilai Sig. 2 tailed dari 21 soal memiliki nilai dibawah alpha atau taraf signifikansi yang bernilai 0.05 (Tabel 2). Pada 9 soal lainnya nilai Sig. 2 tailed tidak dapat diolah oleh aplikasi SPSS karena jawaban dari 30 responden untuk 9 nomor tersebut sama. Selanjutnya uji reliabilitasnya menunjukkan nilai Cronbach alpha's sebesar 0.701 yang menunjukkan kuesioner ini reliabel. Menurut Hadisa et al. (2017), uji reliabilitas menunjukkan hasil yang reliabel apabila dalam pengujiannya memiliki nilai alpha cronbach's lebih besar atau sama dengan 0.70 , sehingga hasil pengujian dengan teori sudah sesuai.

\section{Pengetahuan keamanan pangan mahasiswa}

Mahasiswa yang menjadi responden dalam penelitian ini adalah mahasiwa IPB University angkatan 2017 (angkatan 54) dan akan mengikuti program KKN. Mahasiswa tersebut berasal dari sembilan Fakultas dan yang terbanyak (25\%) adalah dari Fakultas Matematika dan Ilmu Pengetahuan dan dengan dominasi mahasiswa perempuan $(63 \%)$.

Peningkatan pengetahuan keamanan pangan mahasiswa setelah diedukasi dapat dilihat pada Tabel 3 . Pengujian normalitas data dengan uji Kolmogorovsmirnov memberikan hasil bahwa data tidak terdistribusi normal karena nilai Sig. untuk kedua uji dan kedua soal bernilai 0.000 , sehingga dilakukan uji non parametrik Wilcoxon untuk mengukur perbedaan signifikansi data pre dan post-test. Pengujian dengan uji Wilcoxon memberikan hasil berupa adanya perbedaan yang signifikan antara nilai pre-test $(71 \%)$ dan post-test $(87 \%)$ dengan nilai Sig. <0.05 yakni sebesar 0.000. Hasil tersebut juga menunjukkan bahwa intervensi berupa edukasi dengan menggunakan modul Lima Kunci Keamanan Pangan Keluarga secara daring kepada mahasiswa IPB University berpengaruh nyata terhadap perubahan nilai pengetahuan. Melalui pengetahuan, seseorang dapat mempertimbangkan untuk bersikap dan bertindak (Nur'azizaturrahmah 2013). Hal tersebut juga didukung oleh pendapat Notoarmodjo (2007) yang menyatakan bahwa pengetahuan atau kognitif seseorang merupakan domain yang sangat penting untuk nantinya membentuk suatu tindakan atau perilaku seseorang, semakin baik pengetahuan seseorang maka perilakunya pun semakin baik.

Tabel 2. Hasil uji validitas kuesioner $(\mathrm{n}=30)$

\begin{tabular}{|c|c|c|c|c|c|}
\hline Nomor Soal & Sig. 2 Tailed & Valid/Tidak Valid & Nomor Soal & Sig. 2 Tailed & Valid/Tidak Valid \\
\hline 1 & 0.001 & Valid & 16 & 0.013 & Valid \\
\hline 2 & 0.023 & Valid & 17 & 0.023 & Valid \\
\hline 3 & 0.007 & Valid & 18 & 0.007 & Valid \\
\hline 4 & * & Valid & 19 & 0.023 & Valid \\
\hline 5 & 0.001 & Valid & 20 & * & Valid \\
\hline 6 & 0.006 & Valid & 21 & 0.023 & Valid \\
\hline 7 & 0.016 & Valid & 22 & 0.004 & Valid \\
\hline 8 & * & Valid & 23 & 0.002 & Valid \\
\hline 9 & * & Valid & 24 & 0.016 & Valid \\
\hline 10 & 0.006 & Valid & 25 & * & Valid \\
\hline 11 & * & Valid & 26 & * & Valid \\
\hline 12 & * & Valid & 27 & 0.000 & Valid \\
\hline 13 & 0.012 & Valid & 28 & 0.006 & Valid \\
\hline 14 & 0.006 & Valid & 29 & 0.005 & Valid \\
\hline 15 & 0.010 & Valid & 30 & * & Valid \\
\hline
\end{tabular}

Keterangan: *Menunjukkan tidak ada nilai Sig. 2 tailed. Hal tersebut dikarenakan jawaban dari 30 responden untuk nomor tersebut konstan atau sama 
Tabel 3. Hasil evaluasi pengetahuan keamanan pangan $(n=100)$

\begin{tabular}{|c|c|c|c|}
\hline \multirow[b]{2}{*}{ Sub-Bab } & \multicolumn{2}{|c|}{ Persentase Nilai } & \multirow[b]{2}{*}{$\begin{array}{l}\text { Peningkatan } \\
\text { Nilai (\%) }\end{array}$} \\
\hline & $\begin{array}{l}\text { Pre- } \\
\text { Test }\end{array}$ & $\begin{array}{l}\text { Post- } \\
\text { Test }\end{array}$ & \\
\hline $\begin{array}{l}\text { Kunci I: Beli Pangan } \\
\text { yang Aman }\end{array}$ & 74 & $88^{A}$ & 12 \\
\hline $\begin{array}{l}\text { Kunci II: Simpan Pangan } \\
\text { Secara Aman }\end{array}$ & 83 & $93^{A}$ & 10 \\
\hline $\begin{array}{l}\text { Kunci III: Siapkan } \\
\text { Pangan Secara Seksama }\end{array}$ & 71 & $87^{A}$ & 16 \\
\hline $\begin{array}{l}\text { Kunci IV: Sajikan Pangan } \\
\text { Secara Aman }\end{array}$ & 65 & $83^{A}$ & 18 \\
\hline Kunci V: Bersih Selalu & 65 & $83^{A}$ & 18 \\
\hline Rata-rata keseluruhan & 71 & $87^{A}$ & 16 \\
\hline
\end{tabular}

Pengetahuan keamanan pangan mahasiswa diharapkan dapat disebarluaskan kepada sesama mahasiswa atau terhadap masyarakat secara luas karena peran mahasiswa sebagai agent of change dalam masyarakat. Perlunya penyebarluasan informasi keamanan pangan terhadap masyarakat dikarenakan masih terdapatnya masalah keamanan pangan yang antara lain ditunjukkan dari adanya KLB keracuanan pangan. KLB keracunan pangan akibat pangan olahan rumah tangga masih menjadi penyebab utamanya dengan persentase $42.86 \%$ pada tahun 2018 (BPOM 2018).

Berdasarkan hasil tersebut dapat disimpulkan juga bahwa mahasiswa dapat menjadi fasilitator atau kader keamanan pangan sebab nilai post-test sebesar $80 \%$ yang menjadi salah satu persyaratan yang ditentukan oleh BPOM telah tercapai. Pemberian edukasi pembelajaran secara mandiri yang digabungkan dengan diskusi menunjukkan efektivitas yang baik. Hal tersebut sesuai dengan pernyataan Wang et al. (2015) yang menyatakan bahwa pengetahuan remaja akan berkembang lebih baik dan efektif apabila melibatkan aktivitas dengan teman sebayanya melalui diskusi bersama. Selain itu, Yustina et al. (2018) dalam penelitiannya juga mengatakan bahwa intervensi dengan menggunakan metode edukasi dan penggunaan media daring menunjukkan peningkatan pengetahuan yang cukup baik setelah diintervensi.

\section{Pengaruh fakultas asal dan jenis kelamin terhadap pengetahuan keamanan pangan}

Hasil pengujian secara statistik untuk pengaruh fakultas asal dan jenis kelamin mahasiswa terhadap peningkatan nilai setelah diedukasi dapat dilihat pada (Tabel 4). Pengujian untuk normalitas data peningkatan nilai berdasarkan kategori fakultas asal mahasiswa menunjukkan bahwa data tidak berdistribusi normal, pengujian untuk data tidak berdistribusi normal menggunakan uji non parametrik yakni uji Kruskal-Wallis. Hasil uji Kruskal-Wallis terhadap peningkatan nilai berdasarkan kategori fakultas dapat dilihat pada Tabel 4. Nilai sig. hasil pengujian sebesar 0.470 menunjukkan tidak ada perbedaan yang signifikan pada peningkatan nilai antar fakultas. Hal ini menandakan bahwa fakultas asal mahasiswa yang menjadi responden tidak memengaruhi penerimaan mahasiswa terhadap edukasi pengetahuan keamanan pangan yang diberikan.
Selanjutnya uji normalitas data peningkatan nilai untuk kategori jenis kelamin, dapat disimpulkan bahwa baik perempuan maupun laki-laki datanya berdistribusi normal dengan nilai sig. 0.184 untuk perempuan dan 0.133 untuk laki-laki, sehingga uji bivariat dapat menggunakan uji parametrik yakni uji independent $T$ test.

Pengujian dengan independent T-test menunjukkan bahwa nilai sig. 2 tailed sebesar 0.154 . Nilai tersebut lebih besar dari 0.05 sehingga dapat dikatakkan bahwa tidak terdapat perbedaan yang signifikan pada peningkatan nilai antara mahasiswa laki-laki (17\%) dengan perempuan $(15 \%)$.

Tabel 4. Hasil uji statistik terhadap peningkatan nilai berdasarkan kategori fakultas asal dan jenis kelamin $(n=100)$

\begin{tabular}{|c|c|c|c|c|}
\hline \multirow{2}{*}{ Kategori } & \multicolumn{2}{|c|}{$\begin{array}{c}\text { Persentase } \\
\text { Nilai }\end{array}$} & \multirow{2}{*}{$\begin{array}{l}\text { Peningkatan } \\
\text { Nilai (\%) }\end{array}$} & \multirow{2}{*}{$\begin{array}{c}\text { Uji Statistik } \\
\text { Peningkatan Nilai }\end{array}$} \\
\hline & $\begin{array}{l}\text { Pre- } \\
\text { Test }\end{array}$ & $\begin{array}{c}\text { Post- } \\
\text { Test }\end{array}$ & & \\
\hline Fakultas & & & & $\begin{array}{l}\text { Kruskal-Wallis } \\
\text { (sig.) }\end{array}$ \\
\hline $\begin{array}{l}\text { Kehutanan } \\
\text { dan } \\
\text { Lingkungan }\end{array}$ & 67 & 86 & $19^{a}$ & 0.470 \\
\hline $\begin{array}{l}\text { Ekologi } \\
\text { Manusia }\end{array}$ & 72 & 89 & $17^{\mathrm{a}}$ & \\
\hline $\begin{array}{l}\text { Ekonomi \& } \\
\text { Manajemen }\end{array}$ & 66 & 83 & $17^{\mathrm{a}}$ & \\
\hline $\begin{array}{l}\text { Matematika } \\
\text { dan IPA }\end{array}$ & 74 & 89 & $15^{\mathrm{a}}$ & \\
\hline Pertanian & 72 & 87 & $15^{\mathrm{a}}$ & \\
\hline Perikanan & 74 & 84 & $10^{a}$ & \\
\hline Teknologi & 67 & 86 & $10^{\mathrm{a}}$ & \\
\hline Pertanian & & & & \\
\hline Peternakan & 78 & 88 & $10^{\mathrm{a}}$ & \\
\hline $\begin{array}{l}\text { Kedokteran } \\
\text { Hewan }\end{array}$ & 87 & 93 & $6^{a}$ & \\
\hline $\begin{array}{l}\text { Jenis } \\
\text { Kelamin }\end{array}$ & & & & $\begin{array}{l}\text { Independent T-test } \\
\text { (sig. } 2 \text { tailed) }\end{array}$ \\
\hline Laki-laki & 68 & 85 & $17^{a}$ & \\
\hline Perempuan & 73 & 88 & $15^{\mathrm{a}}$ & 0.154 \\
\hline
\end{tabular}

Keterangan: $\mathrm{a}=$ berada dalam satu subset yang sama

\section{Kelayakan materi edukasi lima kunci keamanan pangan keluarga}

Proses intervensi keamanan pangan salah satunya dapat dilakukan dengan memberikan materi edukasi berupa bahan ajar secara daring yang dapat diakses secara mandiri oleh peserta kader keamanan pangan. Menurut Nafi'ah (2017), sebaiknya sebelum suatu modul atau bahan ajar digunakan untuk melakukan intervensi atau edukasi perlu dilakukan evaluasi terhadap bahan ajar seperti mengukur kelayanan isi materi dan tampilan bahan ajar. Evaluasi materi edukasi Lima Kunci Keamanan Pangan Keluarga dalam penelitian ini selain mengukur tampilan dan isi materi juga dilakukan pengukuran manfaat yang dirasakan setelah mengikuti intervensi atau edukasi. Hasil evaluasi bahan ajar dapat dilihat pada Tabel 5 .

Blok tampilan, isi materi, dan manfaat memiliki nilai yang sangat baik karena setiap kriteria untuk tampilan materi edukasi memiliki persentase nilai berkisar $76-100 \%$. Secara keseluruhan rata-rata nilai untuk evaluasi modul Lima Kunci Keamanan Pangan Keluarga memiliki persentase nilai sebesar $81 \%$. 
Menurut Febrianti et al. (2017), suatu bahan ajar dapat dikatakan sangat baik apabila memiliki persentase nilai sebesar $76-100 \%$.

Tabel 5. Skor evaluasi bahan ajar Lima Kunci Keamanan Pangan Keluarga $(n=100)$

\begin{tabular}{lcc}
\hline \multicolumn{1}{c}{ Sub Topik } & Persentase Nilai (\%) & Kesimpulan \\
\hline Tampilan & 81 & Sangat baik \\
Isi materi & 82 & Sangat baik \\
Manfaat & 78 & Sangat baik \\
Rata-rata skor & 81 & Sangat baik \\
\hline
\end{tabular}

\section{KESIMPULAN}

Pengetahuan keamanan pangan mahasiswa IPB University menunjukkan peningkatan sebesar $16 \%$ setelah dilakukan edukasi, dengan nilai awal yang relatif sudah tinggi yaitu $71 \%$. Edukasi keamanan pangan dapat diterima dengan baik untuk semua golongan mahasiswa yang bebeda fakultas asal dan jenis kelaminnya. Materi keamanan pangan berupa modul Lima Kunci Keamanan Pangan Keluarga yang diberikan secara daring menunjukkan bahwa tampilan, isi materi, dan manfaat masuk dalam kriteria yang sangat baik dengan skor masing-masing secara berturut-turut sebesar 81,82 , dan $78 \%$. Hal ini menunjukkan bahwa modul yang dikembangkan untuk diberikan secara daring sudah layak untuk digunakan pada penyuluhan keamanan pangan.

\section{DAFTAR PUSTAKA}

[BPOM] Badan Pengawas Obat dan Makanan Republik Indonesia. 2015. Laporan Tahunan Badan POM RI tahun 2015. Jakarta (ID): BPOM.

[BPOM] Badan Pemeriksa Obat dan Makanan. 2015c. Perka BPOM No 5 Tahun 2015 tentang Perdoman Cara Ritel Pangan yang Baik di Pasar Tradisional. Jakarta (ID): BPOM.

[BPOM] Badan Pengawas Obat dan Makanan Republik Indonesia. 2016. Laporan Tahunan Badan POM RI tahun 2016. Jakarta (ID): BPOM.

[BPOM] Badan Pengawas Obat dan Makanan Republik Indonesia. 2017. Laporan Tahunan Badan POM RI tahun 2017. Jakarta (ID): BPOM.

[BPOM] Badan Pengawas Obat dan Makanan Republik Indonesia. 2018. Laporan Tahunan Badan POM RI tahun 2018. Jakarta (ID): BPOM.

[Kemenkes] Kementrian Kesehatan Republik Indonesia. 2013. Permenkes No. 2 tahun 2013 tentang Kejadian Luar Biasa (KLB) Keracunan Pangan. Jakarta (ID): Kemenkes.

[RI] Republik Indonesia. 2012. UU No. 18 tahun 2012 tentang Pangan. Jakarta (ID): Sekretariat Negara.

Adillah SN. 2019. Pengetahuan Kader Keamanan Pangan Desa dan Kesiapannya Menggunakan Sistem Pembelajaran E-Learning. [Skripsi]. Bogor: Institut Pertanian Bogor.
Ananda RR. 2016. Pengaruh Metode Intervensi terhadap Pengetahuan dan Perilaku Ibu Rumah Tangga di Desa Puraseda tentang Keamanan Pangan. [Skripsi]. Bogor: Institut Pertanian Bogor.

Budiaji W. 2013. Skala pengukuran dan jumlah respon skala likert. J Ilmu Pertanian dan Perikanan 2(2): 127-133.

Hadisa N, Susanti R, Robiyanto. 2017. Uji validitas dan reliabilitas B-IPQ versi Indonesia pada pasien gagal ginjal kronik di RSUD Soedarso Pontianak. J Manajemen dan Pelayanan Farmasi 7(4): 175-181. DOI: $10.22146 /$ jmpf.33340.

Nafi'ah Z. 2017. Pengembangan Modul Keselamatan dan Kesehatan Kerja Untuk Siswa Kelas X Tata Busana SMK Karya Rini Yogyakarta. [Skirpsi]. Yogyakarta: Universitas Negeri Yogyakarta.

Nursalam. 2008. Konsep dan Penerapan Metodologi Penelitian Ilmu Keperawatan. Salemba Medika, Jakarta.

Nur'azizaturrahmah. 2013. Perbedaan Pengetahuan antara Sebelum dan Sesudah Intervensi Penyuluhan Menggunakan Media Leaflet tentang Penyebab Dermatitis dan Pencegahannya pada Pekerja Proses Finishing Mebel Kayu di Ciputat Timur. [Skripsi]. Jakarta: Universitas Islam Negri Syarif Hidayatullah.

Notoarmodjo S. 2007. Kesehatan Masyarakat Ilmu dan Seni. Rineka Cipta, Jakarta.

Febrianti KV, Bakri F, Nasbey H. 2017. Pengembangan modul digital fisika berbasis discovery learning pada pokok bahasan kinematika gerak lurus. J Wahana Pendidikan Fisika 2(2): 18-26. DOI: 10.17509/ wapfi.v2i2.8273.

Triana D, Widyarto WO. 2013. Relevansi kualifikasi kontraktor bidang teknik sipil terhadap kualitas pekerjaan proyek konstruksi di provinsi Banten. J Fondasi 1(1): 182-190. DOI: 10.36055/jft.v2i2.1732

Umar H. 2008. Metode Penelitian untuk Skripsi dan Tesis Bisnis. Raja Grafindo Persada, Jakarta.

Wang D. Stewart D, Chang C, Shi Y. 2015. Effect of school-based nutrition education program on adolescents nutrition-related knowledge, attitudes and behavior in rural areas of China. Environ Health Preventive Med 20(4): 271-278. DOI: 10.1007/ s12199-015-0456-4.

Widi RE. 2011. Uji validitas dan reliabilitas dalam penelitian epidemiologi kedokteran gigi. Stomatognatic 8(1): 27-34.

Yustina E, Lubis R, Keloko AB. 2018. Efektivitas metode diskusi dengan menggunakan media leaflet dan modul terhadap peningkatan pengetahuan dan sikap tokoh masyarakat tentang pencegahan malaria di kecamatan Kutambaru kabupaten Langkat tahun 2015. J Mutiara Ners 1(2): 90-97.

JMP-06-20-09-Naskah diterima untuk ditelaah pada 14 Juli 2020. Revisi makalah disetujui untuk dipublikasi pada 05 Oktober 2020. Versi Online: http://journal.ipb.ac.id/index.php/jmpi 